\title{
Transposition
}

Musique et Sciences Sociales

9| 2021

Musique et sexualité

\section{Sandie Holguín, Flamenco Nation: The Construction of Spanish National Identity}

Madison, University of Wisconsin Press, 2019

\section{Carlos van Tongeren}

\section{OpenEdition}

\section{Journals}

Electronic version

URL: http://journals.openedition.org/transposition/5537

DOI: $10.4000 /$ transposition. 5537

ISSN: 2110-6134

Publisher

CRAL - Centre de recherche sur les arts et le langage

\section{Electronic reference}

Carlos van Tongeren, "Sandie Holguín, Flamenco Nation: The Construction of Spanish National Identity", Transposition [Online], 9 | 2021, Online since 15 December 2020, connection on 23 April 2021. URL: http://journals.openedition.org/transposition/5537 ; DOI: https://doi.org/10.4000/transposition.5537

This text was automatically generated on 23 April 2021. 


\section{Sandie Holguín, Flamenco Nation: The Construction of Spanish National Identity}

Madison, University of Wisconsin Press, 2019

Carlos van Tongeren

\section{REFERENCES}

Sandie Holguín, Flamenco Nation: The Construction of Spanish National Identity, Madison, University of Wisconsin Press, 2019, 384 p.

1 Sandie Holguín's monograph Flamenco Nation. The Construction of Spanish National Identity is a comprehensive study of how flamenco was inscribed into Spanish national identity and became one of the central cultural tropes associated with Spain for travellers and tourists, as well as for institutions and citizens at home. For readers interested in understanding why flamenco is still successfully used to lure numerous tourists first into Spain and thereafter into innumerable tablaos, peñas and chiringuitos across the country's cities and coastlines, this book will provide them with the historical background needed to answer that question.

Divided into three parts and seven chapters, Flamenco Nation is a historiography that studies representations of flamenco in travel narratives, guidebooks, essays, newspaper articles and campaign materials created by non-practitioners of the art form itself. In this way, Holguín focusses on how the role of flamenco has evolved in historical debates about nationhood, from the late $19^{\text {th }}$ century (Restoration Spain) until the end of the Franco-dictatorship in 1975, arguing that there was a fundamental change in conceptions of flamenco. Firstly, travel narratives and intellectual discourses that circulated in Spain and abroad in the $19^{\text {th }}$ century shared the view that flamenco was a degenerate culture. Marginalised Gitano-communities, historically associated with the emergence of flamenco song and dance, provided foreign travellers with seductive 
tokens of Spain's so-called cultural 'backwardness'. At later historical stages, while still operating as a symbol of traditional and exotic culture, flamenco was realigned with discourses of economic progress and successfully incorporated into a transnational tourism industry.

3 An important conceptual contribution from Holguín's book is that it highlights the transnational dynamics that were operative at different stages of Spain's identity formation. The author shows, for example, that Romantic travellers from Britain, France and the United States made essential contributions to that process, alongside Spanish elites who wrote about the outlaw character of flamenco because they repudiated it (Chapters 1 and 2). Later, Holguín goes on to illustrate how a campaign for a Spanish art exhibition in London associated Spain exclusively with flamenco and other folkloric tropes, thereby disregarding the domestic campaigns for the same event that emphasised the country's cultural diversity (Chapter 7). All of this helps the reader understand how processes of identity formation, in terms of both their construction and reception, can be multidirectional and eminently transnational efforts.

The first part of Flamenco Nation provides an informative overview of the emergence of flamenco in the $19^{\text {th }}$ century and the historical processes that shaped Spain and Europe between the French Revolution and Restoration period. Helpful visual support is offered throughout with a series of maps that reconstruct the locations of cafés cantantes in places such as Madrid, Seville and Barcelona. Chapter 1 examines the forging of inter-class alliances around the culture of majismo, a set of proto-nationalist tastes and demeanours that emerged in Madrid as a way to oppose the cultural, intellectual and political influences from France. Among other things, this illuminating chapter lays bare the historical conditions that made Andalusia, in opposition to other parts of Spain, a preferred destination for European travellers. Chapter 2 deals with elite groups who used their writing to agitate against flamenco. Representatives of the Catholic Church, progressive intellectuals and leaders of workers' movements all criticised flamenco, out of dissatisfaction with the social changes brought about by industrialisation and with the fact that mass culture was starting to influence the lives of Spanish citizens.

5 The second part, comprised of chapters 3,4 and 5, discusses the roles of flamenco in projections of regional and national identity in the $19^{\text {th }}$ and early- $20^{\text {th }}$ centuries. It starts with a brief theoretical discussion of the concepts of "regional nationalism" and "cultural regionalism", which are then applied to the cases of Catalonia (Chapter 3) and Andalusia (Chapter 4). In line with the broad overviews of historical periods that Holguín offers at the beginning of other chapters, the first part of chapter 3 reads as a cultural history of Catalan nationalism and deals with flamenco not so much because it was productive for the emergence of regional nationalism in Catalonia -as were, for instance, the choral societies or orfeóns that recuperated and performed traditional Catalan music (p. 108-109) -, but rather because nationalists rejected it. The second part of the chapter, however, does demonstrate that flamenco remained popular in spite of these manifestations of antiflamenquismo, and that Barcelona maintained "an ambivalent and sometimes humorously resigned connection to flamenco" (p. 114).

6 Chapter 4 analyses the roles of flamenco in Andalusian nationalism by honing in on the writings of Blas Infante, who is now officially acclaimed as the father of Andalusian nationalism and who envisioned a libertarian politics for Andalusia that was rooted in the history of flamenco. For instance, by deriving the etymology of the word 
"flamenco" from the Arabic felamengu ('errant, fugitive labourer'), Infante reinterpreted individualism in flamenco performances as a form of libertarianism, based on individual freedom and opposed, thereby, to the totalising tendencies of mass culture in northern Europe. Chapter 5 goes on to explore the dynamics between Spanish and European culture at various World Expositions, most of them located in Paris, in the late $19^{\text {th }}$ century and pre-Civil War years. The Orientalist tropes used at these exhibitions were detested by the elites, who wished to find more realistic projections for Spanish national identity.

7 The third and final part of the book traces a series of shifting attitudes towards flamenco in the $20^{\text {th }}$ century. Chapter 6 explores how religious institutions and groups like Acción Católica under Primo de Rivera, the Second Republic and the first half of the Franco-dictatorship fought against the "tide of modernity" (p. 180), thus contributing to the marginalisation of flamenco through a combination of propaganda, terror and repression. As shown in Chapter 7, flamenco became a renewed source for national pride in the second half of the dictatorship, a time in which Spaniards "colonized themselves for material gain" (p. 205) through folkloric dance spectacles and tourism campaigns.

8 As in earlier parts of the book, Holguín's examination of attitudes toward flamenco under Franco considers a series of conservative discourses and opinions that apply not exclusively to flamenco and that are concerned more generally with the potential dangers of mass culture. By inferring conclusions about flamenco from this wider set of material, Holguín does not always succeed in making a convincing translation from that broader context to specific attitudes towards flamenco. Part of the issue here may be that in most of the sources that Holguín examines throughout Flamenco Nation, flamenco has already been converted into a stereotype; a reified and rather simplistic metaphor that is meant to represent either positive or negative aspects of Spanish national identity. Perhaps the author could have taken account of more specific sources on the art form that would have allowed for a stronger contextualisation of the diverse performative styles and practices of flamenco, as well as of the meanings they acquired for specific individuals and communities. Possible sources that come to mind here are written memoirs by flamenco singers Antonio Mairena and Pepe el de la Matrona, which document the way in which flamencos lived together with the Francoist military in Seville during the Civil War and post-war years. There were other prominent regime representatives, such as José Carlos de Luna and José María Pemán, who were dedicated folklorists and flamenco aficionados. These and other links between the worlds of flamenco and the Primo de Rivera and Franco dictatorships could help shed a clearer light on how flamenco was alternatively repressed, appropriated and admired by authoritarian rulers in Spain's recent history.

Flamenco Nation stops in 1975, the year of Franco's death. An obvious question, then, is how flamenco became relevant for processes of nation-building during Spain's complex transition to democracy. As Holguín states, this topic would require another book (p. 243-244). Yet, in the Coda she does outline a few suggestions for what that book might be about. After describing how the Spanish state and its cultural institutions have continued to use flamenco to attract tourists and promote a coherent notion of Spanish identity - at times at the expense of communities and lesser-known practitioners of the art form- Holguín concludes Flamenco Nation with a consideration of how flamenco can, "when given the right set of circumstances, bear witness to 
human suffering" (p. 257). With this in mind, she briefly analyses recent uses of flamenco by activists in Seville: a dance performance carried out on the International Women's Day for Peace and Disarmament in 2013 to protest against the repression of women by the notorious Francoist general Gonzalo Queipo de Llano, and a flash mob performance by the artivist collective Flo6x8.

Thus shifting her focus from written and printed sources towards a selection of actual performances, Holguín finishes her book, quite unexpectedly, with a discussion of the specific circumstances under which flamenco could achieve a critical potential, an analytical approach that could have been productive at earlier stages of the analysis. Chapter 4, while offering a generally insightful reading of Infante's texts, could perhaps have made a stronger effort to show how Infante mobilised his ideas about flamenco and libertarianism in speeches and gatherings, how those ideas circulated and to what extent they left an imprint on other Spanish intellectuals.

11 At any rate, the legacy of the folklorist discourses and stereotypes studied by Holguín poses relevant questions for future scholarship on flamenco. How do propagandistic uses of flamenco under Franco still have an impact on the attraction that the art form can (or cannot) exert on younger generations? How have centrifugal tendencies and struggles for independence in the contemporary political climate, exacerbated by state arrogance and repression in recent years, turned flamenco into a negative stereotype, perhaps in a way that resembles previous forms of antiflamenquismo? Such questions, of course, reach beyond the scope of Flamenco Nation. As a work of historiography, it is mainly concerned with situating the evolution of flamenco "within the larger Spanish and European historical, cultural, and political trends of the nineteenth and twentieth centuries" (p. 8). Nevertheless, writing a book about flamenco today means that one needs to respond, in one way or another, to the fact that flamenco does not loom as powerfully as before in what Holguín calls "the Spanish imaginary" (p. 8). Scholars, apart from documenting historical developments that have shaped flamenco and other cultural forms, have a privileged position to find new ways of thinking about flamenco beyond national stereotypes. In particular, they can help rethink the connections between art, identity and community so as to pave the way for the emergence of postnational imaginaries.

Holguín's book is a welcome contribution to flamenco scholarship since it delineates a genealogy of previous attempts - most importantly, by Spanish elites and reformersto "cleanse what they perceived to be the flamenco stain from Spain" (p. 15). In a sense, their project was doomed, given that cultural stereotypes are highly resilient. It remains to be seen how this inconvenient stereotype will continue to inform contemporary debates about identity and nationhood in Spain and beyond. 


\section{AUTHORS}

\section{CARLOS VAN TONGEREN}

Carlos van Tongeren is a lecturer in Spanish Cultural Studies at the University of Manchester. His research broadly concerns the cultural production of Spain and Latin America with a focus on literary narrative, essays and performative forms in the post-totalitarian contexts of Spain, Mexico and Cuba. His first book, entitled Comedia y melancolía en la narrativa neopoliciaca (Vázquez Montalbán, Taibo II, Padura) (Brill-Rodopi 2019), examines the intersections between comedy and melancholy in detective fiction from Spain, Mexico and Cuba. Articles related to this research were published in journals such as The Bulletin of Hispanic Studies, Studies in Spanish \& Latin American Cinemas, Confluencia and Revista Iberoamericana. At present, his research deals with performances of memory of the Franco-dictatorship in flamenco culture since the Spanish transition. Outputs related to this project were published in the Journal of Spanish Cultural Studies (18.2) and presented during public lectures with the Plataforma Independiente de Estudios Flamencos Contemporáneos, the Flamenco Biënnale Nederland, and the Instituto Cervantes in Manchester. 